Hegemann, Petra and Berumen, Sergio A. A neoschumpeterian review of the impact of corruption on competitiveness and foreign direct investment.

\title{
A NEOSCHUMPETERIAN REVIEW OF THE IMPACT OF CORRUPTION ON COMPETITIVENESS AND FOREIGN DIRECT INVESTMENT
}

\section{UNA REVISIÓN NEOSCHUMPETERIANA DEL IMPACTO DE LA CORRUPCIÓN SOBRE LA COMPETITIVIDAD Y LA INVERSIÓN EXTRANJERA DIRECTA}

\author{
PETRA HEGEMANN \\ Associate Professor of Applied Economics \\ Frei Universität Berlin \\ petra.hegemann@fu-berlin.de \\ SERGIO A. BERUMEN \\ Reader of Applied Economics \\ Universidad Rey Juan Carlos \\ sergio.berumen@urjc.es
}

Fecha recepción: 25 de octubre de 2010 Fecha aceptación: 8 de marzo de 2011 doi: 10.5209/rev_PADE.2011.v22.2

\begin{abstract}
In countries where the government encourages "donations" and "gifts" from private companies, FDI firms are more likely than their domestic counterparts to engage in corrupt forms of political influence, known as State Captures. Different types of foreign investors engage in particular types of corruption, depending on what competitive advantage they will get out of it. FDI firms with local partners are more likely to engage in State Capture. Larger multinational firms with headquarters overseas rely much less on State Capture, yet are more likely to resort to political corruption and bribery, Kickbacks, in their dealing with foreign governments. Though quite often, foreign direct investors might claim that they are specifically targeted for bribes by local governments, it has been found that there is no evidence that FDI firms pay higher overall bribes than domestic firms, even though they are more likely to engage in specific forms of corruption.
\end{abstract}

KEY WORDS: Corruption, competitiveness and FDI.

JEL: D70, D73, D74.

\section{RESUMEN}

En los países donde los gobiernos fomentan las "donaciones" o "regalos" por parte de las empresas privadas, éstas tienen más posibilidades de verse implicadas en algún tráfico de influencias, conocido como Capturas Estatales. Es el caso de inversores extranjeros que se ven envueltos en actos de corrupción, dependiendo 
Hegemann, Petra and Berumen, Sergio A. A neoschumpeterian review of the impact of corruption on competitiveness and foreign direct investment.

del coste de oportunidad que tengan que asumir. Si bien es cierto que las empresas multinacionales más potentes son menos proclives a incurrir en la Captura Estatal, éstas son más propensas a caer en la corrupción política y en la compra de favores en sus tratos con los gobiernos anfitriones. Ha habido casos en los inversores extranjeros han hecho público su malestar por chantajes de los que han sido objeto por parte de los gobiernos regionales o locales de los países anfitriones. Por otro lado, muy difícilmente se puede demostrar que las empresas extranjeras pagan "comisiones" (en términos coloquiales se refiere a las mordidas) más elevadas que sus homólogas locales, si bien éstas han mostrado una mayor tendencia a aceptar diversas formas específicas de corrupción.

PALABRAS CLAVE: Corrupción, competitividad e inversión extranjera directa.

\section{CORRUPTION BEHAVIOUR AS A SOCIAL PHENOMENON}

Corruption can be defined as a lack of integrity seen in some who have positions of trust. This phenomenon has been seen in many different societies and on many different social levels. From the highest public servants to civilians in companies, corrupt acts such as bribery and payoffs have been seen. Unfortunately, not only is the problem of bribery one that most would deem unethical, it leads only to short term gains for a few while denying long term gains for many. In particular, corruption can hinder the development of nations around the world.

The main problem with corruption is that it creates an unfair advantage in such sectors as business. This leads to a big controversy, for many people believe that competition must be based on an equal level. However, there is a percentage of the population that believe that corruption is simply a part of the status quo, something that needs to be engaged in as a means of gaining efficiencies in business. Therefore two different positions are taken with regard to this subject: some see corruption as unfair in competition and others see it merely as a need for business (Abed and Hamid, 2006). There is a third position, which englobes those who rate various corrupt acts in terms of their level of right or wrong (Alesina and Weder, 2007). Depending on the situation, its background, and other external and internal factors, society views certain acts as correct or not. In those cases ethics are what influence people's decisions to condemn whether an act is corrupted or not.

Nations that are known for high levels of corruption may face major difficulties in being able to gain Foreign Direct Investment (FDI) (OECD, 2010). Obviously, when a nation has a reputation for corruption outsiders might exercise extreme caution in investing in the country. Moreover, and perhaps more important is that a nation that has a reputation for corruption might be disregarded altogether. In turn, the lack of FDI can cost a nation in terms of potential tax revenues, jobs and other benefits that come with new ventures in a nation.

It is difficult to believe that there are no societies less corrupt than the United States (U.S.) which is massively being accused of corrupting less developed countries (LDCs) governments and societies, especially in its immediate sphere of influence. There are many costs for a nation that accompany corruption, these costs can be divided into four sections: i) economic; ii) political; iii) environmental; and iv), social. Economically corruption leads to the reduction of national wealth, for many public 
Hegemann, Petra and Berumen, Sergio A. A neoschumpeterian review of the impact of corruption on competitiveness and foreign direct investment.

officials demand bribes of the citizens on a monthly basis, and government officials would rather sign large high-profile deals such as dams, power plants, and refineries for they earn larger commissions on these projects, and leave more necessary infrastructure projects as schools, hospitals and roads on the side. Furthermore, in the economy of a nation, corruption hinders the development of fair market structures as well as equal competition, creating great costs for its nation.

Politically corruption damages a nation's reputation irrevocably. If a country is not perceived as democratic this influences its relations with all other countries. Offices, institutions and public servants lose all of their legitimacy when they misuse their power for their private advantage. Corruption is even more harmful in developing countries for an accountable political leadership cannot develop in a corrupt climate. Environmental degradation can also a consequence of corruption (López and Mitra, 2002; Weitzel and Berns, 2006). The lack of rules and regulations and the greediness of public servants in developing countries has allowed the North (developed countries) to export its polluting industry South (developing nations) and destroy the nature. Environmentally devastating projects are given preference in funding, because they are easy targets for draining off public money into private pockets.

Norms and values are context-bound and vary across cultures. Gift-giving is part of negotiating and relationship building in some parts of the world. But cultural relativism ends where the Swiss bank account enters the scene. It is a matter of degree: there are limits in all cultures beyond which an action becomes corrupt and unacceptable. The President of Nigeria, Olusegun Obsanjo (1994), commented that, in African tradition, "a gift is made in the open for all to see, never in secret. Where a gift is excessive, it becomes an embarrassment, and is returned".

A big gap between government and citizens accentuates the possibility of corruption occurring for fraudulency is a tool used to direct public procedures to one's own favour, to get around administrative norms, to cut down uncertainty in decision making, to cut through bureaucratic paperwork, etc. Scholarly and peer reviewed research on corruption varies a great deal as researchers have approached the issue of corruption in many ways. The review of the available literature reveals that there are many studies in the general topic of corruption. Moreover, research has been undertaken in terms of corruption and FDI. However, by and large, the research has failed to address the relationship between corruption and decision-making as well as the behaviour of foreign firms in host countries that have a reputation for being corrupt (see Grossman and Helpman, 2001; Bernard, Jensen and Schott, 2006; Blonigen, 2006).

In order to gain a stronger understanding of the context of the study a review of the literature is needed to understand what is known about corruption, FDI, decisionmaking and foreign investors in host countries. A review of the literature allows one to determine potential gaps in scholarly research that can be filled through new studies. Yet while a body of research has been found relating to corruption there are limitations with regard to the research (see Rodriguez et.al., 2006). However, as foreign firms entered foreign nations while new forms were created within developing nations, both managers and scholars became more aware of the magnitude of corruption as well as the need to not only comprehend it, but take action in terms of 
Hegemann, Petra and Berumen, Sergio A. A neoschumpeterian review of the impact of corruption on competitiveness and foreign direct investment.

it. Still, even though researchers from a wide range of social science disciplines, like Elliot (2002) and Gordon and Maiko (2003), have started to examine corruption and fill the gap in terms of an absence of research and literature, these efforts are minimal overall, leading to the need for additional research in this area.

There have been numerous frameworks utilized to examine corruption. According to Shleifer and Vishny (2004) such frameworks have included industrial economic views, resource dependency theory as well as institutional theory. Moreover, the literature on corruption has been based on several sections of the social sciences where scholars within the disciplines have attempted to address views and objectives of their respective disciplines. Each field, Shleifer and Vishny has focused on a few central questions about corruption. The authors reveal that little attention has been paid to the interrelationships that exist between multinational corporations, policy makers, local populations, and managers. This means that there is a lot of space available for additional research, which is one of the aims of this article.

On a broad level the research on corruption has shown that this phenomenon is a major problem to the world economies. In fact, according to Weitzel and Berns (2006) corruption has been recognized not only as a global phenomena but one worth one trillion U.S. dollars annually. Question: The trillion figure is in U.S. or in international terminology, as they tend to differ. This amount represents several forms of bribery including the theft of public assets, nepotism and corrupt leakages from public budgets. Moreover, Weitzel and Berns report that corruption has widely been acknowledged as one of the foremost problems in the developing world, followed by needlessly complex bureaucratic procedures.

Corruption has been examined in terms of many nations such as in Minix Pei's (2006) discussion of corruption in China. Pei argues in his research that even with a major economic boom seen in China, the nation has experienced many problems including waste, the lack of reform and corruption. With specific regard to corruption, Pei asserts that corruption is rampant in China and is seen in several forms such as patronage and nepotism. Many sectors of the economy have been characterized by corruption, such as power, tobacco, financial services, banking and infrastructure. Meanwhile, the country-specific approach has also addressed one of the most well known nations for corruption, Nigeria. According to Herbst (1996), this country has been negatively affected by corruption and even though the nation having strong leaders, the nation is failing due to the problem of corruption. Herbst argues that the failure of Nigeria in terms of being a viable economy is about corruption, not competence. However, like Pei, Herbst fails to reveal a relationship between corruption and FDI.

Herbst does make a strong case for the potential of the Nigerian economy. Similar to Nigeria, Equatorial Guinea is a nation that has oil reserves and thus a potential for a strong economy, particularly in today's oil market. However, as Blum (2005) explains numerous leaders of Nigeria have stolen from the country. And, with the government being critical in the development of the economy, the economy struggles as a result of corruption. Nigeria has become a nation where corruption is seen as a norm, or simply a part of doing business in the nation. Other researchers have also focused on Nigeria as a nation that faces corruption such as de Costa (1996), who argues that there is nothing that cannot be bought in the country. Corruption, de Costa 
Hegemann, Petra and Berumen, Sergio A. A neoschumpeterian review of the impact of corruption on competitiveness and foreign direct investment.

further reveals is found in many realms such as in areas where the government pays employees low wages.

In addition to the country specific studies related to corruption researchers have also examined the consequences of corruption. Werlin (2005) explores the relationship between corruption and its effect on the environment. In Nigeria, corruption has affected the environment in that money allocated to solid waste management was not used appropriately. In fact, the World Bank, the primary global lending institution that aids many Third World, impoverished nations, lent Nigeria over one hundred million dollars for improving its solid waste operations. However, despite the massive loan, only one third of the daily trash has been collected. Clearly, the research shows that corruption can negatively impact the environment (see Fredriksson, List and Millimet, 2005).

However, on a broader level, corruption also affects the functioning of economies. For instance, it can be argued that corruption can aggravate problems of income inequality. Bahre (2005) argues that corruption is the largest obstacle to both social development and economic development. Bahre also reports that within the realm of social development, corruption can harm efforts of improving health as well as the efforts put into providing effective education of children of corruptive nations.

Scholarly research has examined corruption as it relates to FDI. However, the research has not examined companies that have entered nations to do business despite knowing the fact that these countries are corrupted. For example, Cuervo (2006) has argued that host country corruption discourages FDI and asserts that some companies exposed to corruption in their home nations might seek to invest in countries where corruption occurs. This, it might be suggested, relates to how some see corruption as a norm and a part of the status quo needed to gain efficiencies in conducting business activities.

Meanwhile, researchers have also examined corruption in terms of causes and effects with regard to FDI. Researchers Zhao, Kim and Du (2003) studied forty nations over a seven-year period with the data revealing that a high level of corruption as well as a low level of transparency can work against gaining inward FDI. The authors focused on the specific angle of how transparency plays a role in corruption, arguing that corruption is not only an economic phenomenon but also a cultural and political one. However, there has been little research concerning transparency, Zhao, Kim and Du say. The authors believe that even with an increasing interested in the topic of corruption due to the increasing trend of globalization and foreign market entry as well as FDI.

Still, despite Zhao, Kim and Du's argument that there is little data on transparency, other literature has focused on the issue. For example, the OECD (2010) reveals that in cultures of business environment where there is a lack of transparency efforts to combat the corrupt practices are problematic. The article emphasizes that the creation and use of important legislation is vital for attracting possible investors. Companies and individuals that might invest in a nation are greatly influenced by the fact the host country's government is at least willing to do the effort of putting in place legislations and regulations to control actual corruption. Investors are appeased by the fact that governmental institutions willing to combat fraud, and are more inclined 
Hegemann, Petra and Berumen, Sergio A. A neoschumpeterian review of the impact of corruption on competitiveness and foreign direct investment.

to invest if they see that corruption is a concern for the nation. The creation and implementation of the legislation may be more important than the actual legislation at the time of the investment. It is therefore very important to enforce the legislation against corruption as a means of increasing chances of gaining FDI.

One reason why such legislation and the enforcement of it is important, according to Habib and Zurawicki (2002), is because investors do tend to shy away from nations with reputations for corruption. This authors argue that in general, foreign investors avoid corruption due to the view that it is considered wrong. Moreover, foreign investors see corruption as leading to a lack of efficiency in operations. However, the authors, while creating a link between decision-making and FDI in foreign nations, fail to examine the many variables that relate to making choices. Many see corruption as negative and suggest that this reduces FDI in some markets, others do not agree completely. In fact, Hines (2005) argue that while on one level corruption is viewed in a negative manner as it can cost companies a great deal of money in such ways as bribery payoffs, there is another side that some see a positive aspect of corruption. Egger, Loretz, Pfaffermayr and Winner (2006) state that, using bribes can help grease the wheels of commerce. Hence, some companies might find that in paying bribes they are able to gain some efficiencies in business such as the ability to gain licenses, permits and other permissions more quickly compared to a situation where such bribes are not paid. According to Stiglitz (2006), this view of corruption is more common in firms related to forestry, mining and sweat mills (overseas manufacturing), for corruption will allow them to oversee environmental and labour regulations.

Other researchers have also found that some see corruption as necessary. For example, according to a Gallup Poll (2006) rampant corruption is seen as one of the defining characteristics of the post-communist Russia where corruption has become a part of the capitalist culture. The research of the Gallup Poll reveals that many Russians see corruption as a major issue in the nation, with $80 \%$ of respondents in a face-to-face survey saying that yes corruption is widespread in their government and/or country. Moreover, an astoundingly low $7 \%$ of the Russians surveyed are satisfied with the way that corruption is being handled. Still, it seems that corruption has become somewhat of a norm in society (see Gradirovski and Esipova, 2006).

Perhaps most important is that additional Gallup (2010) research suggests that in the ex Soviet-Union, bribery is not always seen as wrong. In fact, many acts that occur in Russia would be considered corrupt under the standards of the Western world, are not viewed as such by Russians. Gallup reports that in Russia gifts and services are not viewed as corrupt by many Russians. Moreover, due to the fact that many Russians have had personal experiences with corruption some have taken a nuanced view of its moral standing and role in society. In fact, research conducted by Gallup found that forty four percent of those surveyed found that it is morally acceptable to use bribery in some cases such as bribing health care practitioners, nurses or doctors, to receive better care in medical care facilities. Meanwhile, thirty two percent of those surveyed believe that it is morally acceptable to bribe officials in academia to have a child admitted to a university or college. Perhaps more troubling is that among younger generation Russians, forty two percent consider bribing in academic establishments as morally acceptable. 
Hegemann, Petra and Berumen, Sergio A. A neoschumpeterian review of the impact of corruption on competitiveness and foreign direct investment.

Some researchers have examined the concept of how companies might influence corruption and FDI. While much of the literature has examined FDI and corruption in how the corruption affects the investment of firms, Kwok and Tadesse (2006) examine how the presence of multinational corporations shapes institutional corruption. The researchers found that the presence of multinational firms in corrupt markets can place pressure in terms of regulatory, demonstration and professionalisation effects and find that the presence of foreign-owned subsidiaries can reduce the level of corruption in a host nation. Regulatory pressures include companies, such as those of the United States, having to follow laws of their home nation, even overseas such as the Foreign Corrupt Practices Act (FCPA) of 1977 (see Hines, 2005). As for demonstration effect, the authors agree that locals learn from the foreign-owned subsidiaries how business is conducted in a non-corrupt manner. Finally, with the professionalisation effect, the authors conclude that multinational corporations can reduce corruption in a foreign nation as they can teach local workers about running an operation without corruption.

The results of the Kwok and Tadesse (2006) study seem to suggest that surprisingly, the entry of a multinational corporation in a foreign nation can have a positive effect on corruption over time. The authors believe that the FDI inflows, that come from nations where typically there is less corruption, brings its norms with it. As a result, with organizations basing their behaviours on norms shaped by their home country's anti-corruption laws, it is expected that the members of the corrupt host nation will attempt to copy the norms of the traditional business practices of the foreign multinational corporation.

Other studies that have linked corruption to FDI include the work of Weitzel and Berns (2006) who in their work on corruption and takeovers discuss how many studies assume that foreign firms are outsiders to the corruption of the host nation and that several outside firms seek local partners as a means of accessing local markets in the host nation. Moreover, the authors state that research has argued that corrupt environments do often lead to the need to employ brokers, middlemen and local partners, leading to the assumption that the costs of corruption are high. Perhaps most important is the affirmation that corruption raises barriers to entry as well as barriers of exit in corrupt markets due to the view that partners in corruption are often tied to each other even after the exchange of funds and/or goods in the corrupt act.

Luo (2006) examines how a multinational corporation that enters a corrupt market operates and/or influences the host nation. Luo evaluates the manner in which multinational corporations manage both political and social forces in a foreign emerging market. Kwok and Tadesse argue that multinational corporations that enter nations can reduce over time the corruption levels of the foreign nations. In contrast, Luo argues that when the multinational company perceives corruption in the host country, the organization's propensity to cooperate and be forward with the government decreases. In fact, the focus that the multinational firm might have on such concepts as "goodhearted contributions" might be very negative for they go against the foreign company's ethics. This only drives the managers of the company to ignore all governmental issues, and manage their company in their own little bubble, and not contributing in any way to reduce the host country's level of corruption. Other findings include that when a multinational corporation finds itself in 
Hegemann, Petra and Berumen, Sergio A. A neoschumpeterian review of the impact of corruption on competitiveness and foreign direct investment.

a nation where it perceives a high level of corruption that it will use bargain at an arms length because of the corruption that exists in the country.

Another interesting part in Luo's research is that the author does reveal the response to corruption among multinational companies operating in corrupt markets. The author states, for example, that research has found that some companies, as a response to corruption, place stress on ethical codes of conduct that their employees must comply with. These codes are sometimes used as means to increase the workers' awareness of corruption and can motivate the workers to seek aid in fighting back against corruption in a host nation. Some companies, Luo reports, make an effort to ensure that workers understand just what corruption is. Overall, Luo does examine the response to perceptions of corruption, yet does so not do so in terms of FDI and decision-making but in terms of a firm's ethical codes.

And the research does point to some potential findings. For example, the research has suggested that some individuals do not see corruption as being negative but simply a part of the status quo, needed in fact to "grease the wheels" to achieve business goals. These exact words have been repeated several times. Perhaps a change might be welcome here. A suggestion is: However some researchers have found that corruption is seen as part of normal business practices in some multinational corporations, and that perhaps this a phenomenon related to sector and not to nationality. Moreover, the research suggests that many people view corruption as a simple part of doing business without much consideration for the ethical issues that surround it. Still, the research has also suggested that some firms do respond to corruption through focusing on their ethics and working to aid their workers operating in corrupt nations of their ethical views and likely the laws that they must follow with regard to engaging in corruption even in foreign nations. It becomes clear that potential findings of the research may likely vary based on views of corruption and ethics and how corruption was perceived to potentially impact the company that has made a decision to enter a nation known for corruption.

Despite the failings of the literature the various authors have advanced literature that allows one to gain a better understanding of corruption as it occurs in various nations, how it affects businesses and economies and to some extent how it affects decision making. It becomes clear that the various researchers who have examined FDI, corruption and to some extent decision-making, have addressed the issues in a variety of ways. However, there is no available literature on the behaviour of foreign firms in host countries. There is much difficulty in obtaining this information, but it is necessary to do so to find out if those foreign investors have participated in their corrupt host country's fight against corruption. Contrary to public thought, FDI may not be the solution to fighting corruption. Observing that there is a gap in the literature concerning findings on the above mentioned subject of academic analyses of corruption, it will be the aim of this thesis to collect and analyse data to find out what the relationship that exists in host countries of FDI and corruption.

\section{FDI IMPACT ON CORRUPTION IN THE DEVELOPING ECONOMIES}

Nowadays it is a given that corruption poses large costs for economic development. There have been many studies that have made evident that higher levels of 
Hegemann, Petra and Berumen, Sergio A. A neoschumpeterian review of the impact of corruption on competitiveness and foreign direct investment.

corruption are associated with lower per capita income. A number of recent studies have shown that corruption- especially in developing countries- reduces FDI. But though most of the focus has been on the extent of foreign investors who have stayed away from the developing countries, comparatively little attention has been given to the behaviour of those that have invested in those countries. Do foreign investors in developing countries import better standards of conduct or do they contribute to the problem? Recently a lot of attention has been focused on this and many ethics codes and multinational legal restrictions have been put into place to encourage investors to meet higher standards of governance than those of the local environment. However there is no evidence of how foreign investors act when they are far away from home.

Table 1. Domestic and Foreign firms in the survey example.

\begin{tabular}{|l|c|c|c|c|c|c|}
\hline \multicolumn{1}{|c|}{ Country } & $\begin{array}{c}\text { Total } \\
\text { firms }\end{array}$ & $\begin{array}{c}\text { Domestic } \\
\text { firms }\end{array}$ & FDI & $\begin{array}{c}\text { FDI } \\
\text { (\%) }\end{array}$ & $\begin{array}{c}\text { Local } \\
\text { HQ }\end{array}$ & Foreign HQ \\
\hline Albania & 160 & 139 & 21 & 71,6 & 12 & 9 \\
\hline Armenia & 125 & 123 & 2 & 85 & 0 & 2 \\
\hline Azerbaijan & 137 & 124 & 13 & 80,1 & 12 & 1 \\
\hline Belarus & 132 & 117 & 15 & 47,7 & 14 & 1 \\
\hline Bulgaria & 130 & 113 & 17 & 56,1 & 17 & 0 \\
\hline Croatia & 127 & 110 & 17 & 46,1 & 17 & 0 \\
\hline Czech Republic & 149 & 116 & 33 & 83,5 & 24 & 9 \\
\hline Estonia & 132 & 106 & 26 & 54,7 & 23 & 3 \\
\hline Georgia & 129 & 111 & 18 & 50,5 & 15 & 3 \\
\hline Hungary & 146 & 119 & 27 & 78,2 & 26 & 1 \\
\hline Kazakhstan & 147 & 120 & 27 & 82,9 & 11 & 16 \\
\hline Kyrgyzstan & 132 & 117 & 15 & 36,3 & 14 & 1 \\
\hline Latvia & 166 & 125 & 41 & 63,5 & 40 & 1 \\
\hline Lithuania & 112 & 106 & 6 & 51,3 & 6 & 0 \\
\hline Moldova & 138 & 122 & 16 & 66,9 & 14 & 2 \\
\hline Poland & 245 & 205 & 40 & 56 & 37 & 3 \\
\hline Romania & 125 & 105 & 20 & 56,9 & 19 & 1 \\
\hline Russia & 552 & 515 & 37 & 54,6 & 31 & 6 \\
\hline Slovakia & 137 & 122 & 15 & 52,9 & 13 & 2 \\
\hline Slovenia & 125 & 108 & 17 & 66,9 & 17 & 0 \\
\hline Ukraine & 247 & 217 & 30 & 45,3 & 28 & 2 \\
\hline Uzbekistan & 126 & 108 & 18 & 49,3 & 17 & 1 \\
\hline Overall & 3619 & 3148 & 471 & 60,9 & 407 & 64 \\
\hline Source: retrieved from Smarzynska and Wei (2000). & & & & \\
\hline
\end{tabular}

Most existing studies of corruption and FDI are based on indices of corruption perceptions at the country level. But to assess the way that foreign firms actually behave in host countries, internal individual firm data is needed to be able to compare the propensity of foreign firms to engage in the country's corruption versus 
Hegemann, Petra and Berumen, Sergio A. A neoschumpeterian review of the impact of corruption on competitiveness and foreign direct investment.

the propensity of domestic firms to do so. A survey that was conducted by the World Bank to 400 firms in 22 developing countries, gives us the necessary data to actually get this inside information on the behaviour of foreign firms in host countries (see Smarzynska and Wei, 2000). This is the source that will be the most used throughout this section to analyse the relationship that exists between foreign firms in corrupt developing countries. Thanks to a survey done in the year 1999 by members of the World Bank, there is finally a study based on data that was collected from actual firms that have had experience in actual corrupt practices.

Table 1 is a summary of the number of firms, domestic and foreign, that were analyzed and the countries where they operate in. The survey that was conducted in 1999-2000, will be a very useful source throughout the research to demonstrate the relationship that exists between FDI and corruption. The survey was done for the following purpose: "to assess the quality of the business environment, including governance and corruption based on the experiences and practices of different firms ${ }^{1}$." And it was distributed in 22 developing countries, interviewing between 125 and 150 firms in each country. The survey distinguishes between multinational firms whose headquarters are located overseas and FDI firms with local headquarters which are in most cases Joint Ventures with a local partner. This difference permits the analysis of different types of FDI firms with different behaviours in the countries that they operate in. Therefore in this case corruption can be analyzed from the perspective of domestic firms versus international ones, as well as among different types of foreign firms.

Drabek and Payne (2006) make a distinction between two forms of corruption:

- State Capture: which they define as the extent to which firms make illicit private payments to public servants in order to influence the formation of laws, rules, regulations or decrees by government organisations.

- Public Procurement Kickbacks ${ }^{2}$ : defined as illicit private payments to public servants to secure government procurement contracts.

These forms of corruption are not the same as Facilitation Payments. The way that Facilitation Payments work, is that the governments extract money from their country's firms, and this money is put into rents (annual or monthly payments, college tuition for the children of government officials) that go to public servants that have the power to intervene in the market and modify rules and legislations in a way to benefit the facilitating firms' activities. The difference is that State Capture and Public Procurement Kickbacks are done for both civil servants and firms to gain rents out of

\footnotetext{
${ }^{1}$ As many of the forms of corruption examined in the survey are illegal in most countries, firms must be expected to be reluctant to admit that they engage in such activities. When the survey was conducted, the problems relate with collecting reliable data were in all moment kept in mind, and efforts were made to assure the interviewed that theirs answers would be kept confidential. The survey questions examine corruption from a number different perspectives, and they were conducted to detect any systematic positive or negative bias among the firms in any given country.

${ }^{2}$ Kickbacks are payments or other types of compensation made in order to influence and gain profit from an individual or company. Essentially, kickbacks are bribes. An individual or company uses kickbacks to gain an unearned advantage, benefit, or opportunity, even if others are more qualified or offer more competitive prices. A relatively simple but serious type of white collar crime, kickbacks hurt business by interfering with the functioning of competition in the marketplace (see Drabek and Payne, 2006).
} 
Hegemann, Petra and Berumen, Sergio A. A neoschumpeterian review of the impact of corruption on competitiveness and foreign direct investment.

the bribes. In Facilitation Payments only government bureaucrats benefit from the rents. Therefore this means that firms are quite willing to participate in State Capture and Public Procurement Kickbacks for they will also be getting something out of the deal. The major problems with these being, first, that public servants were put into position to serve the public not to be served by the public; and second, for each corrupt government bureaucrat we need fifteen corrupt private bureaucrats to keep him in position, so corruption tends to be a social disease.

The graph above shows the percentage of contract value that foreign firms pay as bribes. Implying that French investors would spend $5,6 \%$ of the total of their investment in paying public officials so that the contracts actually took place. The United Kingdom leads the ranking paying 5,9\% of the contract value to public officials, while Turkey is last spending $1,5 \%$ in illicit payments. So Turks are less corrupted than their Western counterparts, a major finding about who corrupt who.

Figure 1, which was put in place in the year 2009, indicates that there is practically no difference between the percentages that FDI and Domestic firms pay in forms of bribes, the first paying $4,7 \%$ of the contract value and the second disbursing $4,8 \%$. This indicates that both types of firms are exposed to corruption and that they participate almost equally in fraudulent acts. As for figure 2 that is below, one can clearly see that there is a correlation between firms that make private illicit payments to influence laws of a country versus the countries that do not.

Figure 1. Corruption deters foreign investors: probability of investment loss due to

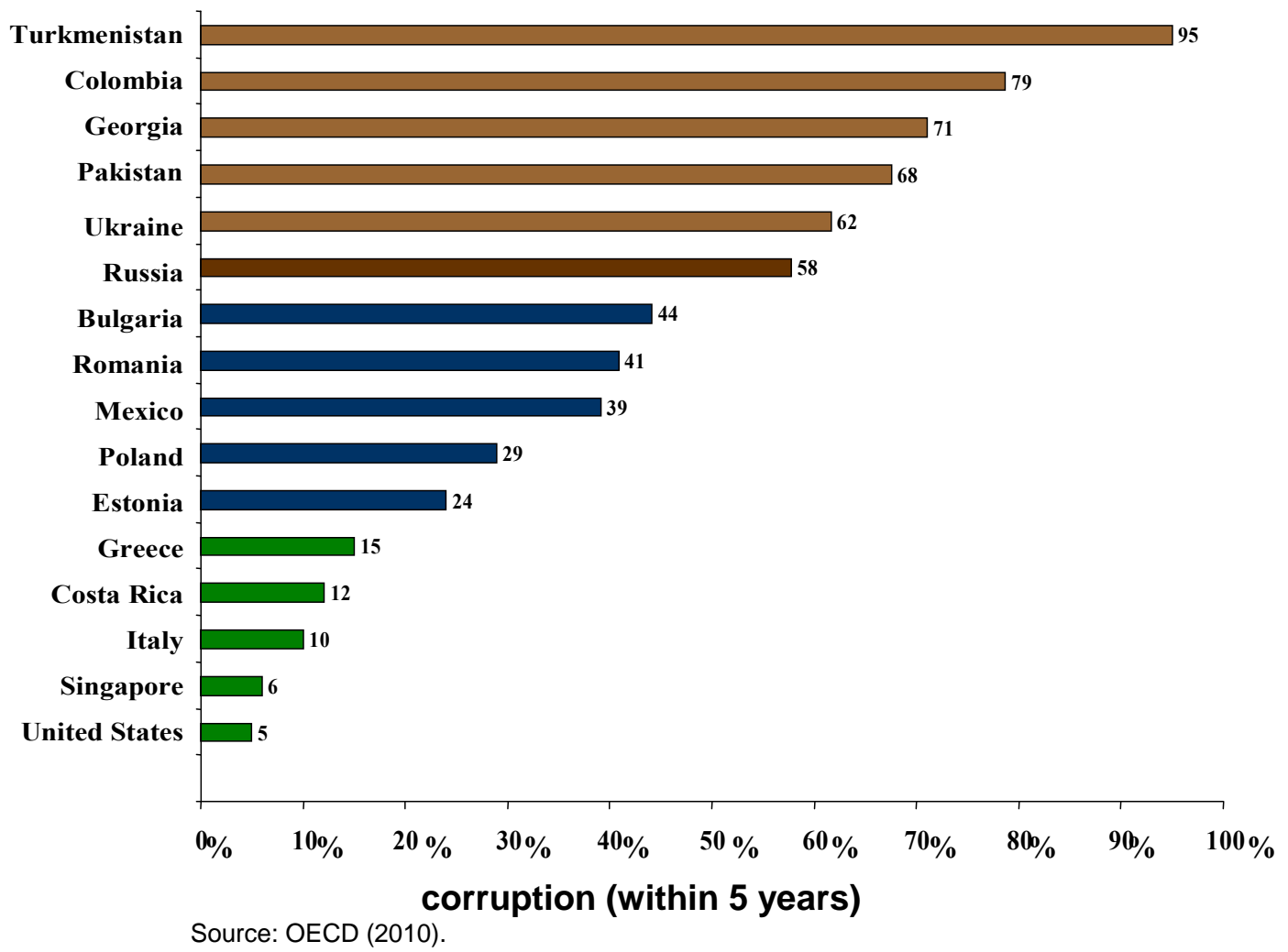


Hegemann, Petra and Berumen, Sergio A. A neoschumpeterian review of the impact of corruption on competitiveness and foreign direct investment.

Figure 2. Public Procurement Kickback Bribes paid by Firms (\% bribe "cut" by Firms with FDI for public procurement contracts)

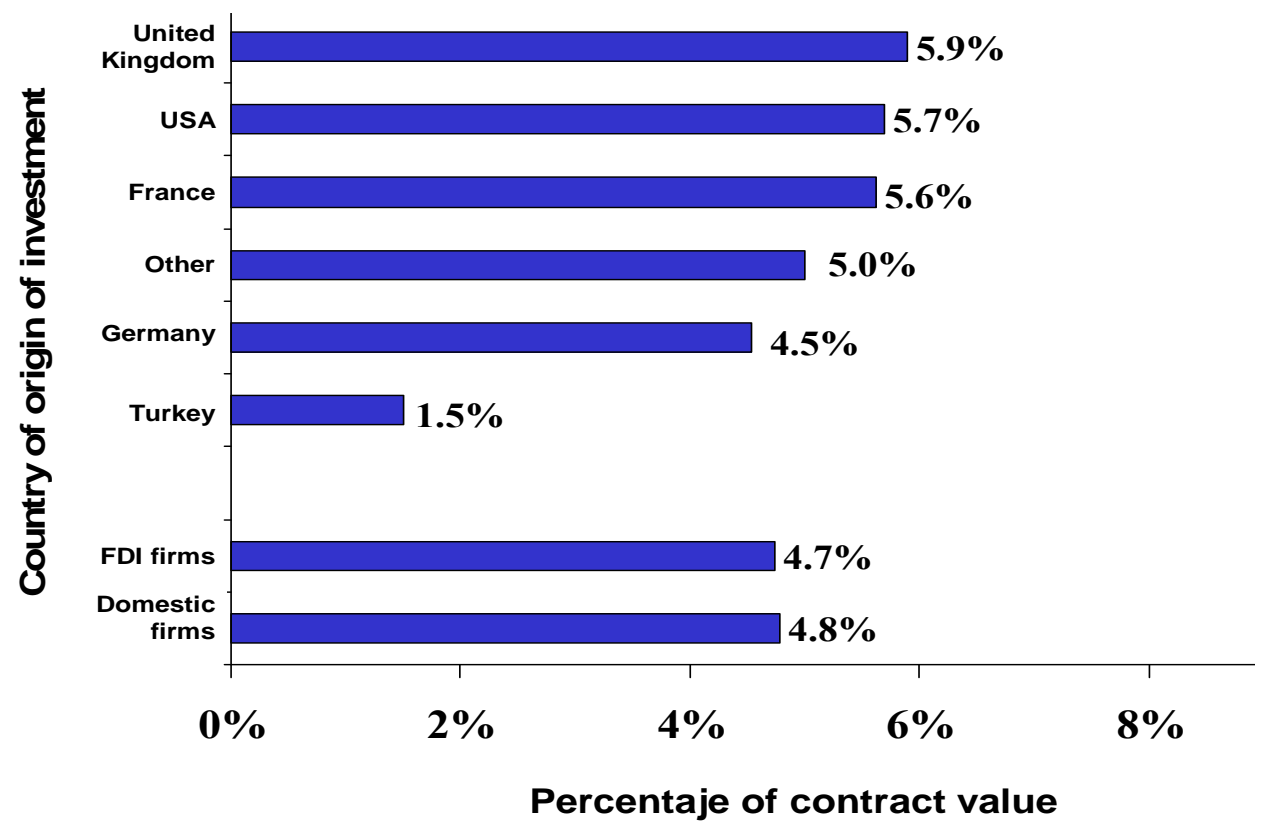

Source: retrieved from the World Bank (2010a).

As is mentioned earlier, State Capture is a type of bribe that economically benefits both government officials as well as the firms that make the payment. Figure 2 clearly states that when a country has corrupt officials (Capture economy) as well as corrupt firms (Captor on the graph), the percentage growth rate of sales is much higher for Captor firms than for Non-Captor firms. This means that when in a corrupt nation, if a foreign firm is also fraudulent; its growth rate is much higher than if the firm follows ethical values. The opposite occurs in non-corrupt economies (Non-Capture economies), where non captor firms are far more successful than captor ones.

So it is possible that corrupted people seek their way to find each other, while noncorrupted people also tend to swarm together. Thus the effect of FDI on local corruption can be of minor importance; the important effect being on the type of FDI being attracted by lawful nations and by corrupted nations. It can also be the incentives to conduct FDI faced by firms in their home countries. If the FDI project is to gain efficiency, then a non-capture country will be chosen; if the reason is to avoid regulations, then a corrupt country shall be selected.

This demonstrates that corrupt nations actually drive foreign firms into corruption, for every businesses' aim is to increase revenues, and when foreign firms realise that the best way to earn more money is by making private payments to modify laws and regulations to their own benefit, they do just that. It seems that corrupt governments actually encourage foreign firms to participate in corruption instead of foreign firms helping developing countries fight bribery.

In the survey given by the World Bank, firms where asked to explain the type of bribery that "firms like them" had been involved in. Some of them reported having made private payments to public servants for the purpose of influencing the content of laws and regulations. Similarly, firms had been asked if they had ever made 
Hegemann, Petra and Berumen, Sergio A. A neoschumpeterian review of the impact of corruption on competitiveness and foreign direct investment.

private payments to public officials to obtain public procurement contracts. Thus a large group of kickback firms can be identified in the sample of firms that were surveyed.

Table 2 provides data of Captor firms and Kickback firms in each country. The exhibit also provides the Average Share of Bribe Payments by firms as a part of their annual revenue. To get the results for the first column "Share of Captor firms", firms were asked whether State Capture in each of the following dimensions (parliamentary legislation, presidential decrees, central bank, criminal courts, commercial courts, political parties) had some kind of impact on their business. Those firms that reported a significant or very significant impact were classified as affected by State Capture in that dimension.

Table 2. Types and Levels of Corruption in Eastern European Economies.

\begin{tabular}{|c|c|c|c|}
\hline Country & Share of Captor Firms & Share of Kickback Firms & $\begin{array}{c}\text { Average Share of Annual } \\
\text { Firm Revenues Paid in } \\
\text { Bribes }\end{array}$ \\
\hline Albania & 11 & 51 & 4 \\
\hline Armenia & 7 & 26 & 4,6 \\
\hline Azerbaijan & 24 & 52 & 5,7 \\
\hline Belarus & 2 & 5 & 1,3 \\
\hline Croatia & 10 & 26 & 1,1 \\
\hline Czech Republic & 7 & 43 & 2,5 \\
\hline Estonia & 5 & 28 & 1,6 \\
\hline Georgia & 8 & 18 & 4,3 \\
\hline Hungary & 4 & 15 & 1,7 \\
\hline Kazakhstan & 6 & 21 & 3,1 \\
\hline Kyrgyzstan & 7 & 19 & 5,3 \\
\hline Latvia & 14 & 22 & 1,4 \\
\hline Lithuania & 14 & 15 & 2,8 \\
\hline Moldova & 12 & 9 & 4 \\
\hline Poland & 9 & 32 & 1,6 \\
\hline Romania & 13 & 39 & 3,2 \\
\hline Russia & 9 & 22 & 2,8 \\
\hline Slovakia & 12 & 35 & 2,5 \\
\hline Slovenia & 10 & 27 & 1,4 \\
\hline Ukraine & 12 & 33 & 4,4 \\
\hline Uzbekistan & 2 & 24 & 4,4 \\
\hline Overall & 9,5 & 26 & 3 \\
\hline
\end{tabular}

Source: retrieved from the World Bank (2010b).

The second column "Share of Kickback firms" represents those firms that traded with the government, and these were asked: how often do firms like yours nowadays need to make extra unofficial payments to public officials to gain government 
Hegemann, Petra and Berumen, Sergio A. A neoschumpeterian review of the impact of corruption on competitiveness and foreign direct investment.

contracts? Finally to obtain the numbers in column 3 "Average share of annual firm revenues paid in bribes", it must be explained that the question was asked in terms of revenues rather than profits because the estimates of revenues are more reliable. "Total payments" refers to total administrative corruption, for the majority of bribe payments are for this purpose.

In all of these countries a similar pattern arises: more firms, whether they are foreign or domestic, pay Kickbacks rather than State Capture, meaning that in developing economies firms are prone to make private payments rather than influence government officials to change the law and the rules and regulations (see figure 3 ). They would rather be doing something illicit through the payment of kickback than "convince" the government to alter the laws so that their practices are viewed as correct. The reason for this attitude is the matter of saving time, rather than waiting for laws to pass through parliament to make their business legal. As an explanation one might say that "Time is Money", and the faster something is done, the better, that is the reason why Public Procurement Kickbacks seem to be the preferred mode of bribery.

Figure 3. Percentage of firms admitting to paying Kickback Bribes by country of FDI origin.

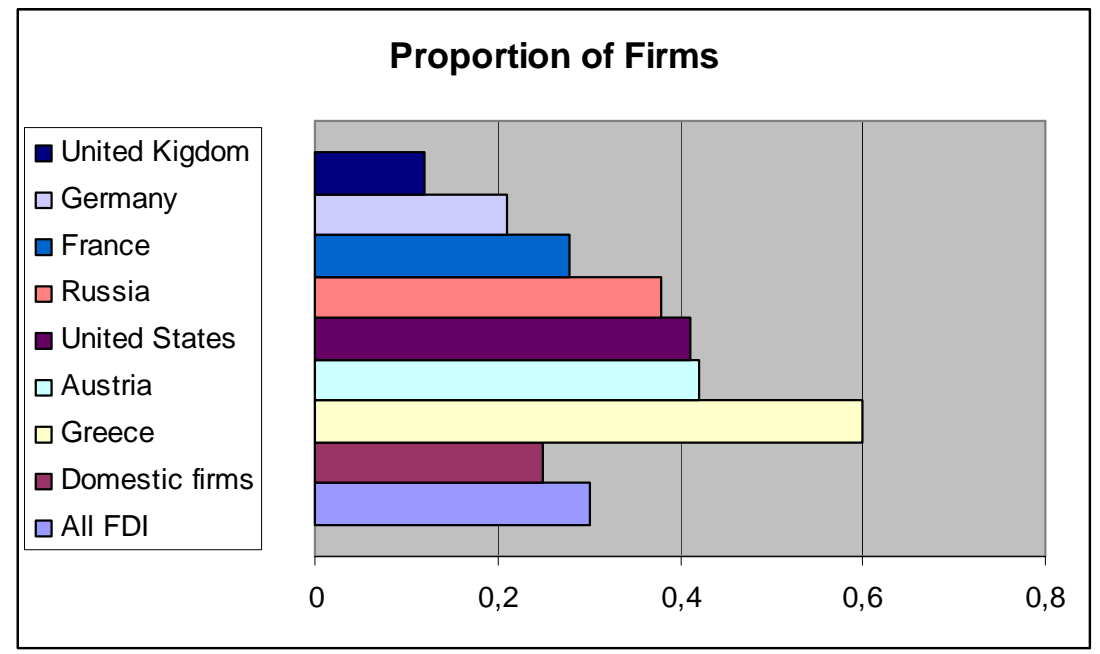

Source: retrieved from Moran (2005).

But the interesting finding is that there is no difference whatsoever between foreign firms and domestic ones, which goes to demonstrate that foreign firms do not have stricter standards of governance for they are participating equally in corruption. This also denies that bureaucrats force foreign firms into paying a larger number of bribes as well as higher sums simply because, being foreign, they must comply with the host country's rules. All in all, foreign firms and domestic seem to be equally guilty in participating in frauds. First time a hear from this from a first world citizen thus my congratulations.

\section{CORRUPTION BY FDI FIRMS}

The question that now arises is the following: Are firms with FDI more or less likely than domestic firms to engage in corruption? A study done by Wei (2003) analyses over 400 firms and divides the countries where the firms are located into different 
Hegemann, Petra and Berumen, Sergio A. A neoschumpeterian review of the impact of corruption on competitiveness and foreign direct investment.

categories depending on whether the companies have high or low levels of corruption in the three areas that have been discussed above: State Capture, Public Procurement Kickbacks and Total Amount of Bribes in annual revenues.

The results of this study reveal an interesting pattern. In terms of level of corruption, FDI and domestic firms pay on average a very similar share of their annual revenues on bribes. The differences start to appear when the tendency to engage in different types of corruption is studied. FDI firms are a bit more likely than domestic firms to pay Kickbacks for performance. The interesting aspect about this is that even though there have been recent developments in ethics codes and compliance procedures, and anti-corruption conventions have taken place, FDI firms do not demonstrate higher standards of behaviour than domestic firms.

As can be seen in figure 4, the study was conducted that reveals that FDI firms, whether they have domestic or international headquarters, are more prone to participate in paying Kickbacks than local firms. More so, it is the enterprises with international headquarters that engage the most in Public Procurement Kickbacks, up to a $40 \%$ of these firms participate in this type of bribery. With respect to State Capture there is also a difference between FDI firms and domestic ones.

In nations with significant State Capture problems FDI firms are almost twice as likely as domestic firms to engage in efforts to capture the State. But in countries where State Capture is rarely practiced, FDI firms are much less likely than domestic ones, as can be seen in figure 5 .

The explanation that most would give for this kind of behaviour would be that foreign investors might be the bait of the corrupt country's government officials. It is quite possible that in a corrupt environment public servants would discriminatingly ask foreign firms with little experience and knowledge of the country for rent. However in the analysis of figure 4 this reasoning is rejected, therefore keeping in mind that when a FDI firm engages in State Capture there are many benefits for the FDI firm itself (which implies that managers often willingly choose to take a corrupt path for they shall be very well remunerated in turn), which leads us to believe that it is all a strategy formulated by FDI firms to earn greater margins. The aim of any firm is to increase shareholder wealth and gain bigger profits, and it seems that FDI firms have woven a strategy around corruption to so just that.

Having investigated the comparison between foreign investors and domestic firms, it is noted that there are various differences within FDI firms. FDI firms can be divided into two categories: those with local headquarters - mainly Joint Ventures with local partners- and those with headquarters abroad- mainly establishments of multinational firms. Differences are expected in the propensity of these types of firms to engage in corruption.

Multinationals usually have greater resources for ethics training and compliance procedures; they are more concerned about their reputation and have somewhat higher risks of being caught if participating in bribery. In contrast, foreign investors often seek local Joint Venture partners who "understand how to get things done" in their countries and have more extensive personal networks to facilitate business. Such differences affect their tendency of each type of FDI firm to engage in corruption. 
Hegemann, Petra and Berumen, Sergio A. A neoschumpeterian review of the impact of corruption on competitiveness and foreign direct investment.

Figure 4. Firms that pay procurement kickbacks (on those that trade with the State) $\%$ of firms

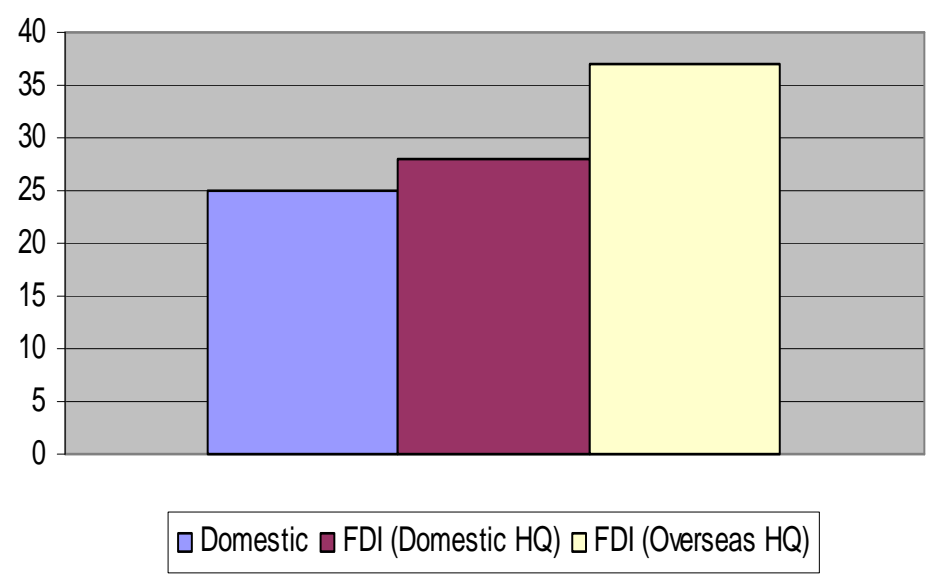

Source: retrieved from the World Bank (2010a).

Figure 5. Practice of State Capture in different countries (in high capture countries)

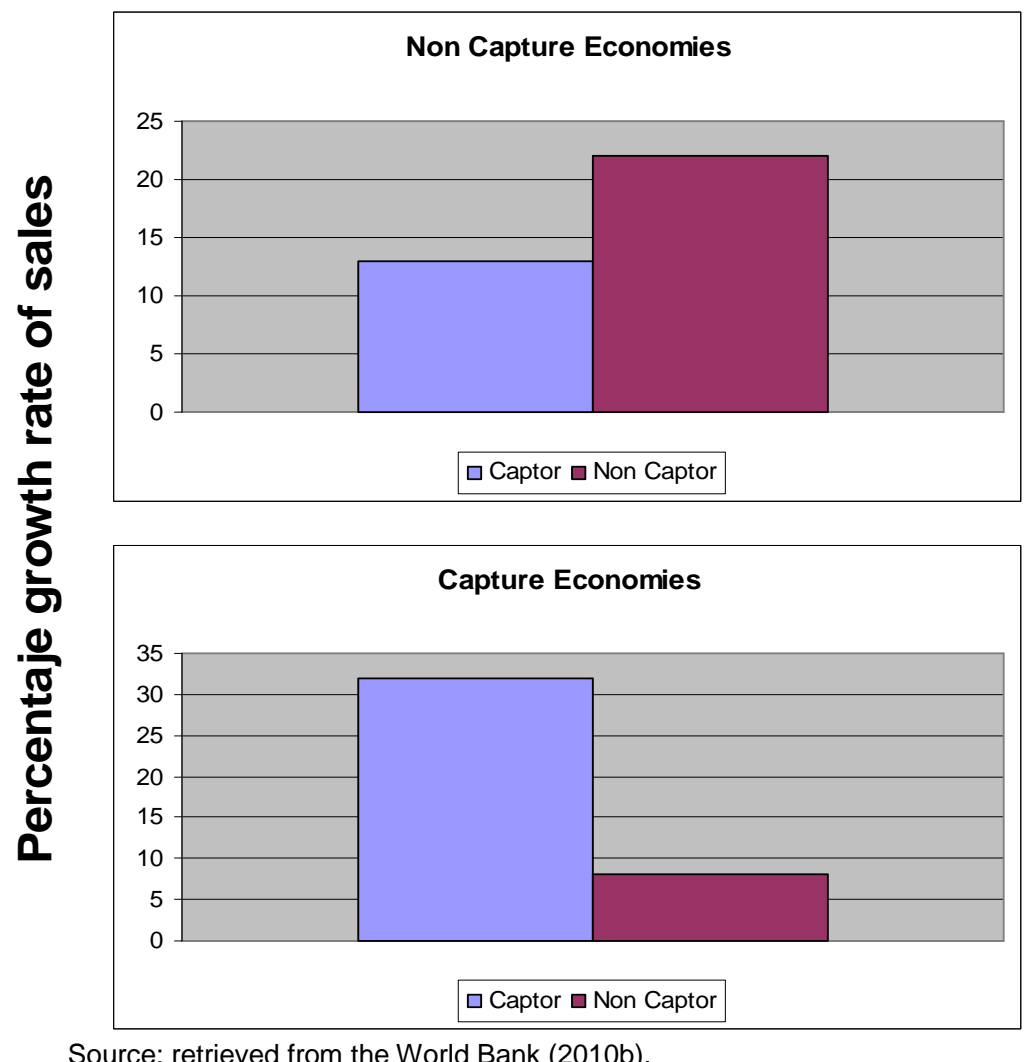

Table 3 presents data on the tendency of FDI firms with local headquarters and FDI firms with foreign headquarters to engage in State Capture and pay Public Procurement Kickbacks, as well as the Total Bribes Paid. Again the data reveals a repetitive pattern. FDI firms with local headquarters are much more likely to engage in State Capture than those with foreign headquarters, especially in high capture countries. The FDI firms with local headquarters also pay considerably higher levels of bribes. FDI firms with foreign headquarters are more likely to pay procurement 
Hegemann, Petra and Berumen, Sergio A. A neoschumpeterian review of the impact of corruption on competitiveness and foreign direct investment.

kickbacks in dealing with the state in highly corrupt environments. Over $50 \%$ of the FDI firms with foreign headquarters working in highly corrupt countries said that they had paid such kickbacks (see figure 6).

Table 3. Characteristics of FDI and corrupt behaviour

\begin{tabular}{|l|c|c|c|c|c|c|c|c|c|}
\cline { 2 - 10 } \multicolumn{1}{c|}{} & \multicolumn{3}{|c|}{ Share of Captors Firms 1 } & \multicolumn{3}{c|}{ Share of Kickback Firms 2 } & \multicolumn{2}{c|}{$\begin{array}{c}\text { Total Bribes Paid (as a share of } \\
\text { annual revenues) } 3\end{array}$} \\
\hline & $\begin{array}{c}\text { All } \\
\text { Counties }\end{array}$ & $\begin{array}{c}\text { High } \\
\text { Capture }\end{array}$ & $\begin{array}{c}\text { Low } \\
\text { Capture }\end{array}$ & $\begin{array}{c}\text { All } \\
\text { Countries }\end{array}$ & $\begin{array}{c}\text { High } \\
\text { Kickbacks }\end{array}$ & $\begin{array}{c}\text { Low } \\
\text { Kickbacks }\end{array}$ & $\begin{array}{c}\text { All } \\
\text { Countries }\end{array}$ & $\begin{array}{c}\text { High } \\
\text { Bribes }\end{array}$ & $\begin{array}{c}\text { Low } \\
\text { Bribes }\end{array}$ \\
\hline $\begin{array}{l}\text { Domestics } \\
\text { Firms }\end{array}$ & 9 & 10,4 & 7,3 & 25,2 & 34 & 17,5 & 3 & 3,8 & 1,8 \\
\hline $\begin{array}{l}\text { FDI Firms } \\
\text { Local HQ }\end{array}$ & 12,5 & 19,9 & 4,5 & 28,2 & 33,3 & 23,3 & 3 & 4,8 & 1,4 \\
\hline $\begin{array}{l}\text { FDI Firms } \\
\text { Foreign HQ }\end{array}$ & 5,3 & 6,3 & 4,9 & 36 & 53,8 & 16,7 & 1,3 & 1,6 & 0,9 \\
\hline
\end{tabular}

Source: retrieved from Luo (2009).

Figure 6. Practice of State Capture in Different countries: capture economies vs. non capture economies.

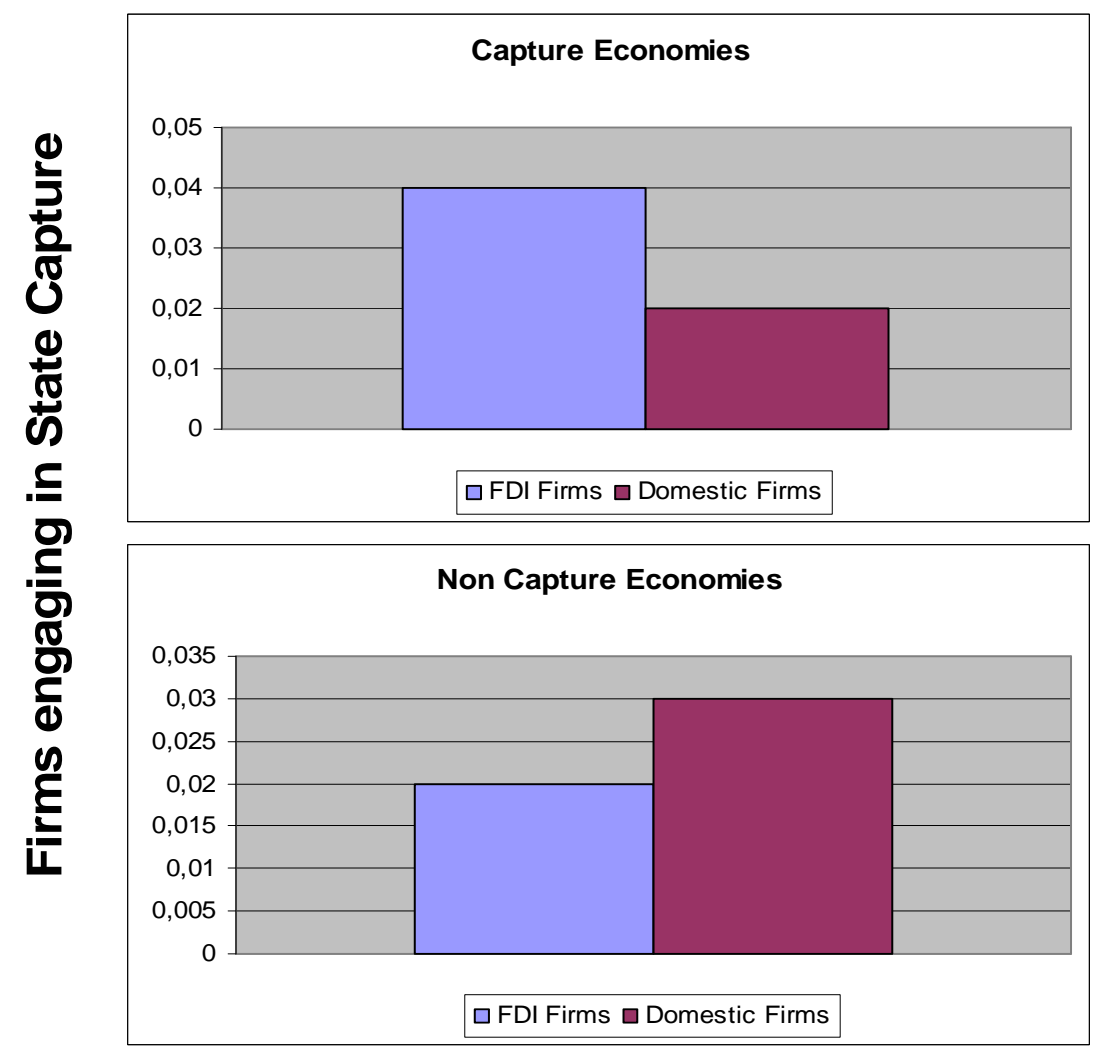

Source: retrieved from the World Bank (2010a).

These results suggest that foreign investors might choose the type of corruption to engage in on the basis of their comparative advantages. "Local" FDI firms with strong contacts in the host country's political and economic environment choose to seek advantages through State Capture (i.e. through influencing the formation of various laws, rules and decrees). FDI firms with foreign headquarters have fewer ties and contacts in such structures and focus more on private payments to public officials and bureaucrats that grant specific contracts in working with the state. This again 
Hegemann, Petra and Berumen, Sergio A. A neoschumpeterian review of the impact of corruption on competitiveness and foreign direct investment.

reflects a more strategic approach to corruption on the part of firms. Up until now it seemed that corruption was something general that firms were forced into to be able to do business in their host countries. But throughout this investigation it is turning out that firms actually study corruption, and employ the form that will give them the higher benefit. An inference in the mental height of Dr. Watson! The problem being resource deviation from $\mathrm{FDI}$ and manufacturing to rent seeking and corruption analyses which certainly must diminish resources worldwide and favour income concentration at the host country, let alone the development and parliamentary approval of competition diminishing institutions.

Corruption is now a state-of-the art, not something to shy away from, simply another economic factor that exists in the market where the firm is operating, and like interest or exchange rates, firms are managing to use corruption in the way that will advantage them the most and lead their business to higher overall revenues. The risks that corrupt practices pose are something that the whole world nowadays is conscious about. In 1977 the Unites States decided to take some kind of action against corruption and the FCPA (v.g. the Act prohibits USA firms from using bribes to maintain or secure business in foreign countries) was created (see Hines, 2005). More recently, seeing that corruption was becoming a problem closely linked to any kind of business in every single country, the OECD created the Convention on Bribery of Foreign Public Officials that was signed at the end of 1997 (see Oman, 2000). However very little attention has been paid to these measures and so far they have failed to reduce corruption worldwide.

As it has been shown throughout this section, there is significant variation in the conduct of foreign investors from different countries with respect to corruption. What many believe is that these differences might be related to differences in the regulatory environments, meaning that countries with less rigorous standards of corporate conduct are more corrupt than others simply because they can get away with it. To identify the impact of anti-corruption legislations a study by Shleifer and Vishny (2003) was conducted where they divided the countries into three different groups:

- The unregulated countries: those which have no legislation constraining the behaviour of their firms in foreign countries. Since all OECD members (and 5 non-members) signed the Convention, the unregulated countries all come from outside the OECD.

- Those countries that have approved the OECD Convention and those that have signed, but not yet ratified it at the time of the survey. ${ }^{3}$

- USA firms. These constitute a separate group since that have been subject to the FCPA for many years prior to signing and ratifying the OECD Convention. Which unfortunately has come to be a major act of hypocrisy, at least as seen from Latin America.

The following graphs and figures study the extent to which legislation leads to changes in behaviour. Common sense makes one expect that USA firms should be the least corrupt, for there have been anti-corruption legislations in their country for

\footnotetext{
${ }^{3}$ The precise rules concerning the coming into force of the Convention can be found in www.oecd.org. For the purpose of this paper, it must be noted that this Convention entered into force with the first group of countries on February $15^{\text {th }} 1999$ and for other countries subsequently as it was ratified domestically.
} 
Hegemann, Petra and Berumen, Sergio A. A neoschumpeterian review of the impact of corruption on competitiveness and foreign direct investment.

the longest period of time, thus punishing those who commit corrupt acts, and, as is mentioned above, this supposedly reduces to propensity of firms to engage in corruption. Following this line of thought, OECD convention countries would be the ones to follow USA enterprises as the least likely to engage in corrupt acts due to the convention signed at the end of 1997 therefore leaving Unregulated Countries last as the most corrupt (OECD, 2009).

Table 4 examines the conduct of foreign investors and the relationship with anticorruption legislation, together with the corresponding results for the whole group of foreign investors and the domestic firms for comparison. The hypothesis that legislation constrains the behaviour of foreign investors should be confirmed by showing lower results of corruption by USA firms (column 4), then by OECD Convention Countries (column 2) and leaving Unregulated Countries the ones with the higher percentages of corruption. Surprisingly this pattern does not emerge, and, in fact, the US investors, supposedly the most constrained, do not show lower levels of corruption than either OECD Convention countries or the Unregulated countries, and in some cases appear to be significantly higher. USA (FCPA) firms rank highest in "Share of Kickback Firms" with $42,7 \%$ and also lead the group in "Number of Observations" with $63 \%$ versus $60 \%$ in Unregulated Countries and $31 \%$ in OECD Convention Countries. USA firms actually rank second in Total Bribes Paid.

Table 4. Legislation in Source Country and corrupt behavior

\begin{tabular}{|l|c|c|c|c|c|}
\hline $\begin{array}{c}\text { FDI Source Country } \\
\text { (by anti-corruption legislation) }\end{array}$ & $\begin{array}{c}\text { Unregulated } \\
\text { Countries }\end{array}$ & $\begin{array}{c}\text { OECD } \\
\text { Convention } \\
\text { Countries * }\end{array}$ & $\begin{array}{c}\text { FCPA } \\
\text { (United States) }\end{array}$ & $\begin{array}{c}\text { All FDI } \\
\text { Firms }\end{array}$ & $\begin{array}{c}\text { Domestic } \\
\text { Firms }\end{array}$ \\
\hline Total Bribes Paid & 4,7 & 2,3 & 3,6 & 2,8 & 3 \\
\hline Share of Captor Firms & 16,7 & 9,8 & 16,7 & 11,5 & 9 \\
\hline Share of Kickback Firms & 31,8 & 27,3 & 42,9 & 29,2 & 25,2 \\
\hline Number of Observations & 60 & 310 & 63 & 471 & 3148 \\
\hline
\end{tabular}

${ }^{*}$ excludes US firms.

Source: retrieved from OECD (2009).

Table 5 makes these claims more statistically precise, by computing pair wise significance tests for the difference between the level of corruption among the various groups. These tests confirm that neither US firms nor firms from the OECD Convention Countries exhibit lower propensity than firms from Unregulated Countries to engage in these common forms of corruption, though total bribe payments from OECD Convention countries are generally lower, USA firms do not exhibit lower levels of corruption, in fact following these tables, in some cases they show higher levels. Thus regulation has, up to now, a minor influence; so once again incentives should be looked at.

Table 5. Comparison of legislation in source country and corrupt behavior

\begin{tabular}{|l|c|c|c|}
\hline & $\begin{array}{c}\text { Share of Captors } \\
\text { Firms }\end{array}$ & $\begin{array}{c}\text { Share of Kickback } \\
\text { Firms }\end{array}$ & $\begin{array}{c}\text { Total Bribes Paid (\% } \\
\text { of annual revenues) }\end{array}$ \\
\hline Unregulated Countries OECD & 16,7 & 31,8 & $4,7^{* *}$ \\
Convention Countries & 9,8 & 27,3 & 2,3 \\
\hline Unregulated Countries FCPA & 16,7 & 31,8 & 4,7 \\
(USA) & 16,7 & 42,9 & 3,6 \\
\hline OECD Convention Countries & 9,8 & 27,3 & 2,3 \\
FCPA USA) & 16,7 & 42,9 & $3,6^{* *}$ \\
\hline
\end{tabular}

Source: retrieved from OECD (2009). 
Hegemann, Petra and Berumen, Sergio A. A neoschumpeterian review of the impact of corruption on competitiveness and foreign direct investment.

\section{CONCLUSIONS}

In countries where the government encourages "donations" and "gifts" from private companies, FDI firms are more likely than their domestic counterparts to engage in corrupt forms of political influence, known as State Captures. Different types of foreign investors engage in particular types of corruption, depending on what competitive advantage they will get out of it. FDI firms with local partners are more likely to engage in State Capture. Larger multinational firms with headquarters overseas rely much less on State Capture, yet are more likely to resort to political corruption and bribery, Kickbacks, in their dealing with foreign States.

Though quite often, foreign direct investors might claim that they are specifically targeted for bribes by local governments, it has been found that there is no evidence that FDI firms pay higher overall bribes than domestic firms, even though they are more likely to engage in specific forms of corruption. Moreover, it has been demonstrated that foreign investors actually earn high returns on corrupt acts, meaning that FDI firms actually receive a substantial amount of the rents from corruption. This evidence therefore rejects the view that foreign investors are forced into paying bribes. Following the evidence collected in a survey conducted in 19992000, legal acts to prevent bribery, such as the USA FCPA and the OECD Convention on Bribery of Foreign Public Officials, have not led to higher standards of corporate conduct among foreign investors. 
Hegemann, Petra and Berumen, Sergio A. A neoschumpeterian review of the impact of corruption on competitiveness and foreign direct investment.

\section{REFERENCES}

Abed, George T. and Hamid R. Davoodi, "Corruption, Structural Reforms and Economic Performance in the Transition Economies". IMF Working Paper, 2006, WP/06/132.

Alesina, Alberto and Beatrice Weder, "Do corrupt governments receive less foreign aid?". National Bureau of Economic Research Working Paper , 2007, 7108. NBER Cambridge, Massachusetts.

Bahre, Erik, "How to ignore corruption: reporting the shortcomings of development in South Africa". Current Anthropology, 2005, 46 (1), February, pp. 107-121.

Bernard, A.B.; Jensen, J.B. and Schott, P.K., "Importers and Multinationals: A Portrait of the Firms in the U.S. that Trade Goods", NBER Working Paper No. 11204, June 2005.

Blum, Justin, "U.S. Oil Firms Entwined in Equatorial Guinea Deals", The Washington Post, September 7, http://www.washingtonpost.com/wp-dyn/articles/A11012005Sep7.html

Blonigen, B.A., "Foreign Direct Investment Behavior of Multinational Corporations", NBER Working Paper, Winter 2006.

Cuervo, Álvaro, "Who cares about corruption?". Journal of International Business Studies, 2006, 37 (6), Nov, pp. 807-823.

De Costa, Peter, "The politics of settlement", African Report, 1996, 38 (6), Nov-Dec, pp. 53-57.

Drabek, Zdenek and Payne, Warren, "The impact of transparency on Foreign Direct Investment". World Trade Organisation Working Paper, 2006, ERAD-99-02.

Egger, P., Loretz, S., Pfaffermayr, M. and Winner, H., "Corporate Taxation and Multinational Activity", CESifo Working Paper Series, CESifo Working Paper No 1773, 2006.

Elliot, Kimberly Ann, "Corruption and the Global Economy". Journal of International Business Studies, 2002, Apr, pp. 557-560.

Fredriksson, Per G.; List, John A. and Millimet, Daniel L., "Bureaucratic corruption, environmental policy and inbound US FDI: theory and evidence". Journal of Public Economies, 2005, Vol 87, pp. 1407-1430.

Gallup, Corruption in Russia: Is Bribery Always Wrong?, New York, Gallup Poll News Service. November 15, 2010.

Gordon, Kathryn and Maiko Miyake, Deciphering codes of corporate conduct, Paris, OECD, 2003.

Gradirovski, Sergei and Esipova, Neli, Corruption in Russia: Greasing the Wheels to Get By, Gallup Poll News Service. November 14, 2006.

Grossman, Gene M. and Helpman, Elhanan, "Protection for Sale". American Economic Review, 2001, 84 (4), pp. 833-850.

Habib, Moshin and Zurawicki, Leon, "Corruption and Foreign Direct Investment". Journal of International Business Studies, 2002, 33 (2), Summer, pp. 291-308.

Herbst, Jeffrey, "Is Nigeria a viable state?". The Washington Quarterly, 1996, 19 (2), Spring, pp. 151-173.

Hines, James R., "Forbidden Payment: Foreign Bribery and American Business after 1977". National Bureau of Economic Research Working Paper, 2005, 5266. NBER, Cambridge, Massachusetts.

Kwok, Chuck C.Y. and Tadesse, Solomon, "The MNC as an agent of change for host-country institutions: FDI and corruption", Journal of International Business Studies, 2006, 37 (6), November, pp. 767-786. 
Hegemann, Petra and Berumen, Sergio A. A neoschumpeterian review of the impact of corruption on competitiveness and foreign direct investment.

López, R. and Mitra, Siddhartha, "Corruption, Pollution and the Kuznets Enviroment Curve", Journal of Environmental Economics and Management, 2002, 40 (2), September, pp. 137-150.

Luo, Yadong, "Political behavior, social responsibility, and perceived corruption: a structuration perspective", Journal of International Business Studies, 2009, 37 (6), November, pp. 747-767.

Moran, Theodore H., Foreign Direct Investment and Development: The new policy agenda for developing countries and countries in transition, Institute for International Economics, 2005.

Obasanjo, Olusegun, "Positive Tradition Perverted by Corruption", The Financial Times, 14 October 1994.

OECD, Corruption Report (2001-2010), Paris, OECD, 2010.

OECD, Transparency for FDI: investment is partly about taking risks, though not just any risk. In fact, transparent systems where the judicial framework is efficient and corruption is low tend to receive more investment, Paris, OECD, 2009.

Oman, Charles, Policy competition for Foreign Direct Investment: A study of competition among governments to attract FDI, Paris, OECD Development Center, 2000.

Pei, Minix, "The dark side of China's rise: China's economic boom has dazzled investors and captivated the world. But beyond the new high-rises and churning factories lie rampant corruption, vast waste, and an elite with little interest in making things better. Forget about political reform. China's future will be decay, not democracy". Foreign Policy, 2006, 153, March-April, pp. 32-40.

Rodriguez, P., Siegel, D.S., Hillman, A. and Eden, L., "Three lenses on the multinational enterprise: politics, corruption, and corporate social responsibility", Journal of International Business Studies, 2006, November, pp. 733-747.

Shleifer, Andrei and Vishny, Robert, "Corruption". Quarterly Journal of Economics, 2003, pp. 599-617, Harvard University Press.

Shleifer, Andrei and Vishny, Robert, "Politicians and Firms". Quarterly Journal of Economics, 2004, pp. 995-1025, Harvard University Press.

Smarzynska, Beata and Wei, Shang-Jin, "Corruption and the composition of Foreign Direct Investment: Firm Level Evidence". World Bank Working Paper, 2000, 2360.

Stiglitz, Joseph E, “Cómo hacer que funcione la globalización”, Taurus, 433 p, 970770-732-1

Wei, Shang-jim, "How taxing is corruption on international investors", National Bureau of Economic Research Working Paper, 2003, 6030.

Weitzel, Utz and Berns, Sjors, "Cross-border takeovers, corruption, and related aspects of governance", Journal of International Business Studies, 2006, November, pp. 786-807.

Werlin, Herbert H., "Corruption in a third world country: why Nigerians cannot handle garbage", World Affairs, 2005, 168 (2), Fall, pp. 79-85.

World Bank, Public Procurement Kickback Bribes paid by Firms, Washington, D.C. The World Bank, 2010a.

World Bank, Anticorruption in Transition: Confronting the Challenge of State Capture, Washington D.C., The World Bank, 2010b.

Zhao, John Hongxin, Kim, Seung $\mathrm{H}$. and Du, Jianjun, "The impact of corruption and transparency on Foreign Direct Investment: an empirical analysis", Management International Review, 2003, 43 (1), January, pp. 41-63. 